DOI: 10.35784/IAPGOS.29

\title{
DATA-BASED PREDICTION OF SOOT EMISSIONS FOR TRANSIENT ENGINE OPERATION
}

\author{
Michèle Schaub \\ Wismar University of Applied Sciences, Faculty of Engineering, Maritime Department
}

Abstract. Global maritime transport is one of the causes of air pollution. Annex VI of the International Maritime Organisation's (IMO) International Convention for the Prevention of Pollution from Ships (MARPOL) refers to air pollution. Air pollution is mainly caused by the conversion of energy in internal combustion engines, in particular in the case of transient engine operation. The main pollutant is soot. It is an impure carbon substance of various sizes, resulting from incomplete combustion of hydrocarbons. This document concerns data-based modelling of soot emissions - the main component of exhaust particles - in transient engine operation. In a unique manoeuvring aid system, the prediction of exhaust emissions will become a new element. If the navigator knows the consequences of his actions, the human role will be strengthened in relation to the decision making on energy-efficient and emission-poor vessel traffic, in particular during manoeuvres. Thanks to the mathematical model, the soot formation process during stationary engine operation - at constant speed and load - will be mapped first. The model will then be extended to simulate engine operation and soot formation in the transition phase.

Keywords: ship emissions, data processing, predictive models

\section{PRZEWIDYWANIE EMISJI SADZY W PRZYPADKU PRZEJŚCIOWEJ PRACY SILNIKA W OPARCIU O DANE}

\begin{abstract}
Streszczenie. Globalny transport morski jest jedna z przyczyn zanieczyszczenia powietrza. Załacznik VI do Międzynarodowej konwencji o zapobieganiu zanieczyszczeniu morza przez statki (MARPOL) Międzynarodowej Organizacji Morskiej (IMO) odnosi się do zanieczyszczeń powietrza. Zanieczyszczenie powietrza jest głównie powodowane przez konwersję energii w silnikach spalinowych, w szczególności w przypadku przejściowej pracy silnika. Głównym zanieczyszczeniem jest sadza. Jest to zanieczyszczona substancja węglowa różnej wielkości, będąca wynikiem niepelnego spalania węglowodorów. Niniejszy dokument dotyczy modelowania emisji sadzy - glównego sktadnika czastek spalin, w pracy silnika w warunkach przejściowych w oparciu o dane. W unikalnym systemie wspomagania manewrów, przewidywanie emisji spalin stanie się nowym elementem. Jeżeli nawigator zna konsekwencje swoich działań, to rola czlowieka zostanie wzmocniona $w$ odniesieniu do podejmowania decyzji o energooszczędnym i ubogim $w$ emisje spalin ruchu statków, w szczególności podczas manewrów. Dzięki modelowi matematycznemu,w pierwszej kolejności zostanie odwzorowany proces powstawania sadzy podczas stacjonarnej pracy silnika - przy statych obrotach i obciążeniu. Następnie model ten zostanie tak rozszerzony, aby umożliwić symulację pracy silnika i powstawania sadzy $w$ fazie przejściowej.
\end{abstract}

Słowa kluczowe: emisje ze statków, przetwarzanie danych, modele predykcyjne

\section{Introduction}

During ship manoeuvres the ship's longitudinal, transversal and rotational velocities are changing continuously. The cause of these changes are newly set rudder, engine or thruster commands or environmental influences as wind or current. All the external and internal impacts on the ship's motion have influence on the behaviour of the ship's engines. The ship's exhaust gas composition depends on the transient engine operation. They have to adapt rotational speed and torque in order to fulfil the required settings. The engine command sets the required engine speed (engine revolutions) or the propeller pitch. New thruster commands or rudder angle settings lead to a new resistance of the ship's hull and thus to a different propeller inflow and counter torque for the engine. To fulfil the required engine settings, the engine control unit (ECU) adapts the amount of injected fuel. The engine speed is the time-dependent integration of the difference between engine and propeller torque divided by the inertia of the powertrain (1).

$$
n_{t+1}=n_{t}+\frac{M_{E}-M_{P}}{J} \times \Delta t \times \frac{60}{2 \pi}
$$

A disequilibrium between propeller and engine torque is the indicator of transient engine operation. The engine control unit has to act on the fuel injection in order to comply with the given order. During the transient engine operation when the load increases the air-fuel ratio becomes too small. This is the main cause which leads to an incomplete combustion of the injected fuel. Thus soot particles in different sizes arise [9]. This issue is widely described in literature, e.g. in [2], [8] and [11]. Whilst [2] reflects a forum on soot formation with various discussions on chemical and thermodynamic approaches, the latter two authors focussed on the application and improvement of existing thermodynamic soot models. Isermann et al. [11] considers the data-based emission modelling for high-speed diesel engines. One of those approaches was adopted for medium-speed ship diesel engines and is presented in this paper.

\section{General Conditions}

\subsection{Regulations regarding particulate matters}

Annex VI of the International Convention for the Prevention of Pollution from Ships (MARPOL) of the International Maritime Organisation (IMO) regulates the ship's air pollution. Regulations 13 and 14 [4] concern the nitrogen oxides $\left(\mathrm{NO}_{\mathrm{X}}\right)$, the particulate matters $(\mathrm{PM})$ as well as sulphur oxides $\left(\mathrm{SO}_{\mathrm{X}}\right)$. For sea-going vessels built since 1st January 2016 with more than $130 \mathrm{~kW}$ per engine and sailing within Emission Control Areas (ECA) the nitrogen oxides must not exceed the requirements defined in TIER III.

Sulphur oxides are restricted by mass fraction of the used fuel oil whereas particulate matters, of which soot forms the significant part, are only mentioned in the regulation's header. A reduction of sulphur in the fuel oil leads to less PM. But nevertheless, low sulphur diesel still produces PM in rough amounts when combustion is incomplete.

The formation of the greenhouse gas $\mathrm{CO}_{2}$ essentially depends on the total fuel oil consumption and on the type and carbon content of the used fuel oil. The Energy Efficiency Design Index (EEDI) should enable to monitor the $\mathrm{CO}_{2}$ emissions. Most of the world's ocean-going vessels obtain their propulsion energy from diesel fuels of different quality. The presented method focusses on this kind of ships and takes the formation of PM to demonstrate the research work in an exemplary way. With little adaptation, the method can also be applied to $\mathrm{NO}_{\mathrm{X}}$ emissions, for example.

\subsection{Test bed engine and measurement equipment}

An MAN 6L23/30 engine serves as test bed. The machine is located on the campus of Wismar University. It is a 4-stroke marine diesel engine. Its specification is shown in Table 1. The MAN 6L23/30 engine is mostly assigned for education of marine engineers. 
Table 1. Test bed engine specification

\begin{tabular}{|c|c|}
\hline \multirow{2}{*}{ Parameter } & Test bed engines \\
\hline & MAN B\&W 6L23/30 \\
\hline Type & $\begin{array}{l}\text { medium speed 4-stroke } \\
\text { marine diesel engine }\end{array}$ \\
\hline Bore & $225 \mathrm{~mm}$ \\
\hline Stroke & $300 \mathrm{~mm}$ \\
\hline Rated output & $1050 \mathrm{~kW}$ \\
\hline Rated speed & $900 \mathrm{~min}^{-1}$ \\
\hline Compression Ratio & $13.5: 1$ \\
\hline Fuel injection system & Unit injector System \\
\hline
\end{tabular}

For research purpose the fixed measurement equipment was enhanced by a portable Pegasor Mi3 particle sensor in order to measure PM during transient engine operation. The measuring principle is based on determining the number of particles smaller than $2.5 \mu \mathrm{m}$. By calibrating the equipment with a mean particle size, the corresponding mass in $\mathrm{mg} / \mathrm{m}^{3}$ is calculated. [10]

\subsection{Ship model and engine module}

For the integration of the data-based model an already existing simulation environment, called SAMMON, is used. SAMMON stands for Simulation Augmented Manoeuvring Design \& Monitoring System [5]. The mathematical ship model represents movements with 3 degrees of freedom (DOF): longitudinal, transversal and rotational speeds around the vertical axis. It is based on a system of highly non-linear equations for representing the ship's hydrodynamic behaviour. Fig. 1 shows the onlineprediction from a ferry ship entering a port. Even though the ship is still in straight forward motion, the prediction immediately reacts on changed rudder or engine settings.

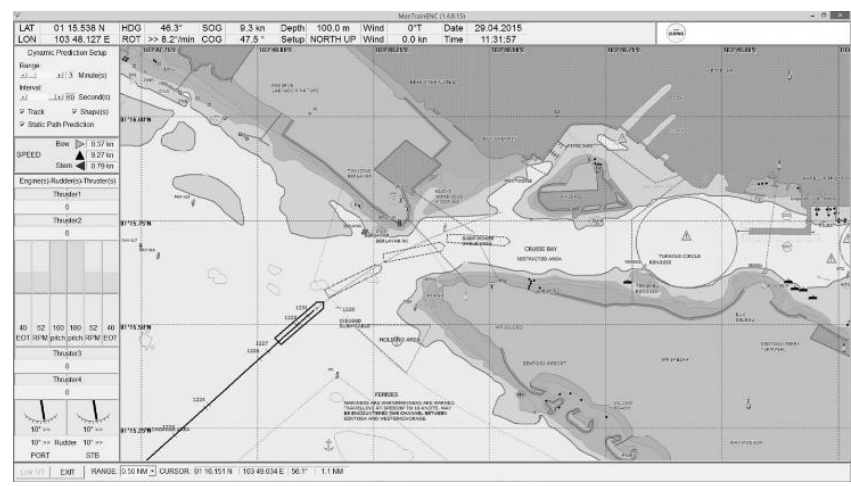

Fig. 1. Manoeuvring assistance software SAMMON for predicting and monitoring ship's behaviour in confined waters [10]

SAMMON Software allows to parameterize several ship types. It can be used for pre-planning of manoeuvre sequences, for online-monitoring or for debriefing after having completed manoeuvres.

The ship model is equipped with an engine interface. Currently, the engine module only consists of a lookup table where the target-actual-difference of engine speed enters. A new engine torque derives from it which is accurate enough to only simulate the ship's motion. To calculate fuel consumption and emissions, the calculated engine torque fails to be useful. Therefore, a PI controller algorithm is implemented which determines the amount of fuel injected in one time step. This is the basis for the calculation of soot emissions.

The proposed data-based modelling of soot will extend the SAMMON software in the future.

\subsection{Rapid Advanced Prediction \& Interface Technology (RAPIT)}

The kernel of the above mentioned manoeuvring assistance software SAMMON is formed by a technology called Rapid Advanced Prediction \& Interface Technology (RAPIT). RAPIT is a kind of fast-time simulation which enables to calculate up to 24 minutes of the simulation process ahead in only one second of real time and to display the results in a sophisticated interface.

The data-based soot model shall fulfil these requirements. This is one of the reasons why an empirical, data-based model was chosen instead of a theoretical model. While a theoretical model must calculate every degree of crank angle and take into account mechanics, thermodynamics and reaction kinetics, an empirical data-based model can save a lot of computing time being a blackor greybox model. The disadvantage, however, is the high effort required to obtain sufficient data in a good quality.

\section{Data acquisition for data-based modelling}

\subsection{Data origin}

Soot is the main part of particulate matters (PM). PM are solid components of engine exhaust gas emissions, e.g. hydrocarbons and soot as well as inorganic sulphates. The diameter varies between less than 10 nanometers and more than $1 \mu \mathrm{m}$.

A chemical reduction takes place at the beginning of soot formation followed by a planar growth of polycyclic aromatic hydro-carbons. Van der Waals forces lead to soot nucleation which is followed by coagulation, accumulation and addition of sulphates. These formation steps are superimposed by soot oxidation. Soot oxidizes with $\mathrm{OH}$ radicals and $\mathrm{O}_{2}$ at high temperatures in competition with carbon monoxide [3]. The difference between reduction and oxidation can be measured in the exhaust gas duct with a standard sampling rate of one second. By means of the already introduced Pegasor Mi3 particle sensor (see section 1.2), the measurements for particles took place. The measurement for the other relevant engine data was taken from the fixed measurement system of the machine laboratory.

Even though for reasons of better understanding theoretical, but time-consuming models are more substantiated, they are not applicable for the present studies. Apart of not being completely described and understood, they would still need too much computing time than RAPIT would allow for (see section 1.4).

\subsection{Experimental design}

For these studies, the test bed engine is not a shipborne diesel engine. Nevertheless, the experimental setup was designed with real ships in mind.

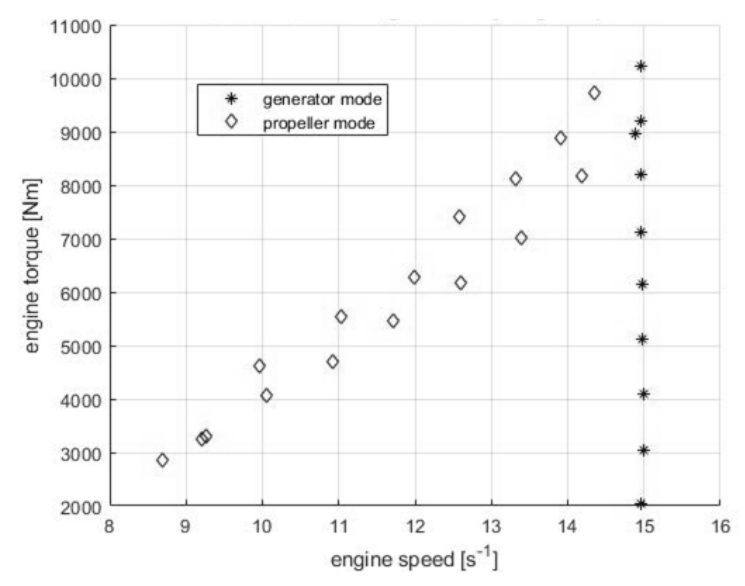

Fig. 2. Engine map with measurement points on two propeller curves (100\% and $85 \%)$ and generator curve

First of all, the distinction between generator and propeller mode is of great importance:

- Propeller mode means that the torque/speed relation follows the propeller curve within the engine map. A load change leads to a change in torque and engine speed simultaneously.

- Generator mode requires a constant or nearly constant engine speed whereas load changes only affect the engine torque. 
At a first step, these stationary measurements serve for establishing a stationary model, which can then be extended by transient parts. Attention is to be payed to numerous data of high quality covering as many input/output combinations as possible (Fig. 2).

The experimental design also provides for load changes of varying magnitude on each of the two propeller and the one generator curves as will be shown in Fig. 7 .

\subsection{Determination of model input and output}

During the data analysis, existing measurement data were searched for which have a clear influence on the soot formation. Finally, the decision was made on the injected fuel mass $\left(\mathrm{m}_{\mathrm{B}}\right)$ and current engine speed ( $\mathrm{n}_{\mathrm{act}}$ ). Fig. 3 shows the combustion chamber in which soot is formed by the above described reduction and oxidation process. This process depends mainly on the currently injected fuel mass and the dwell time in the combustion chamber represented by the engine speed.

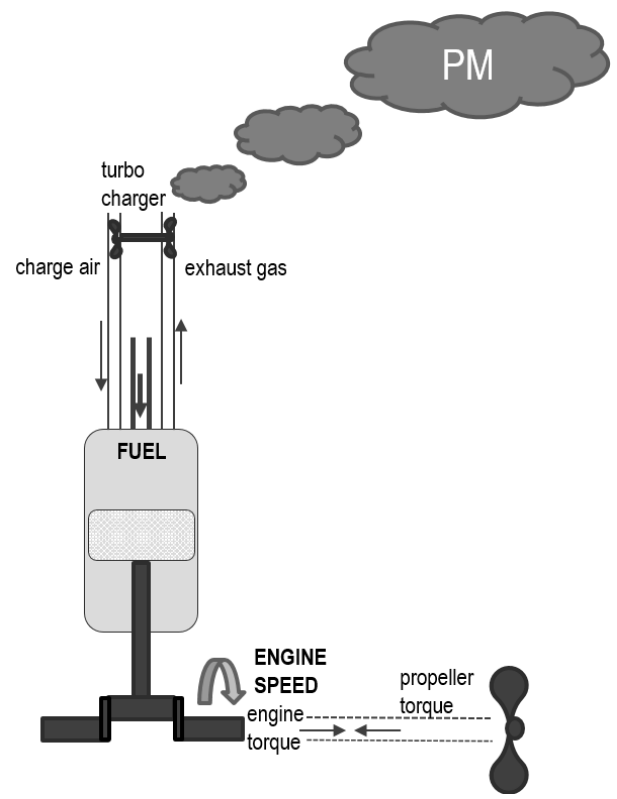

Fig. 3. Model sketch of combustion chamber and adjacent system

These findings lead to the conclusion that a MISO (multiple input, single output) model with two inputs and one output will be necessary.

\section{Static Artificial Neural Network (ANN)}

\subsection{Decision to implement an ANN}

Data-based models do not need any information about physical, chemical or other laws and relationships that determine the processes to be modelled if they are purely black-box models. There are many data-based model architectures to be considered when facing a problem as the one described above [6].

An Artificial Neural Network (ANN) architecture has been chosen due to its relatively good interpolation characteristic and its flexibility regarding input dimensions. For a first approach to create a static network, the Multilayer Perceptron (MLP) being a widely known ANN architecture, has been implemented. Fig. 4 is a sketch of the ANN architecture used for calculating PM by entering the two inputs fuel mass and engine speed.

The $\mathrm{q}$ neurons of the hidden layer $\left(\mathrm{h}_{1}\right.$ to $\left.\mathrm{h}_{\mathrm{q}}\right)$ are called perceptrons. The two inputs $\mathrm{m}_{\mathrm{B}}$ and $\mathrm{n}_{\text {act }}$ are each multiplied by one synapse weight when entering a perceptron in order to intensify or attenuate the effect on the neuron. All input signals are summed up and enter a nonlinear sigmoidal activation function. Therein, a transformation takes place which result is forwarded to the output layer, where the amount of PM is calculated out of the sum of all the perceptron outputs.

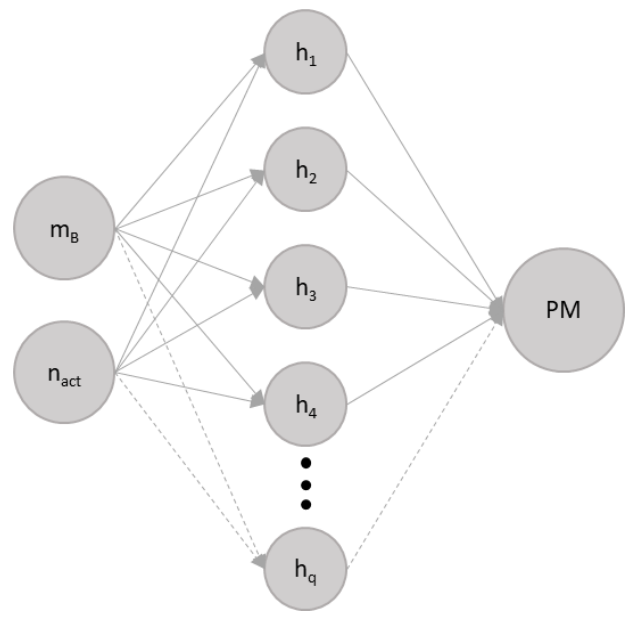

Fig. 4. MLP network with two inputs and one output. The number of neurons in the hidden layer $(h)$ is to be determined

\subsection{Determination of number of hidden neurons}

The present MISO problem is only three dimensional for the static observation. The ANN must fit the measurement points in Fig. 5 as good as possible. The training of the ANN is done by backpropagation using the Levenberg-Marquardt algorithm.

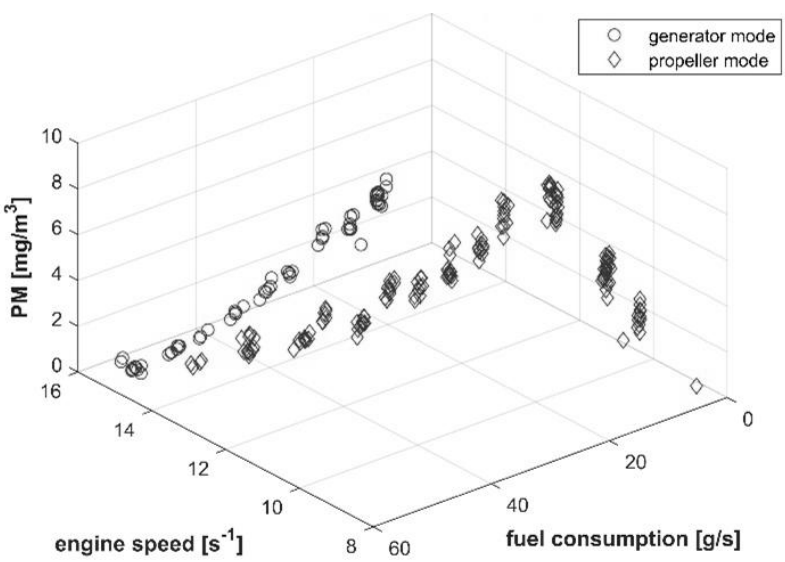

Fig. 5. Distribution of measurement data for input $\left(m_{B}, n_{\text {act }}\right)$ and output variables (PM/soot)

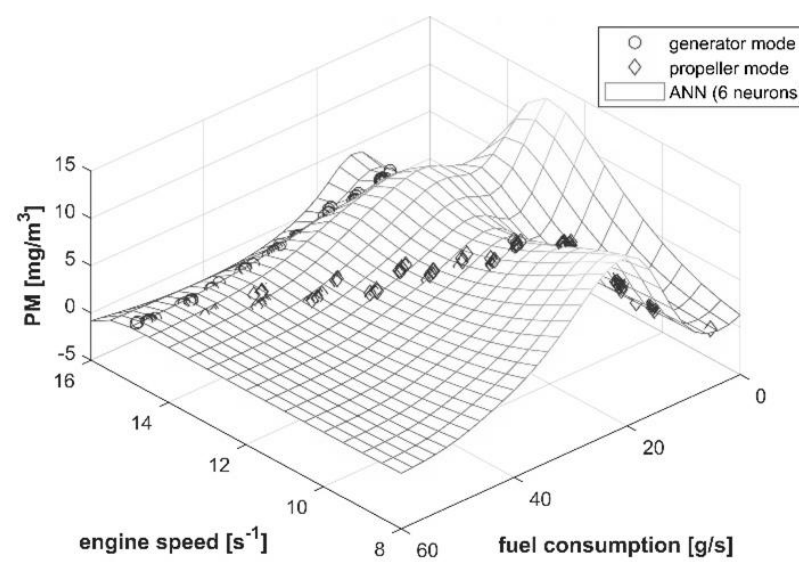

Fig. 6. Trained ANN with 6 neurons in the hidden layer

A $\mathrm{k}$-fold cross validation took place in order to determine the necessery number of neurons. The smallest modell error could be reached with 6 up to 15 neurons in the hidden layer. The absolute error in this range is about $0.3 \mathrm{mg} / \mathrm{m}^{3}$ which corresponds with the scattering of measurement data, see Fig. 5. Fig. 6 shows the shape of the ANN with 6 neurons. More neurons mean also more curvature in the ANN and possibly more distance from a physically interpretable model. 


\subsection{Application for transient engine operation}

A static ANN with 6 neurons has been used for simulation of the transient engine operation. The result shows the big difference between the development of PM in stationary and transient engine operation. The zoomed section in Fig. 7 is an example to show how close the stationary operation would be approached by the ANN and how dynamics are not yet implemented.

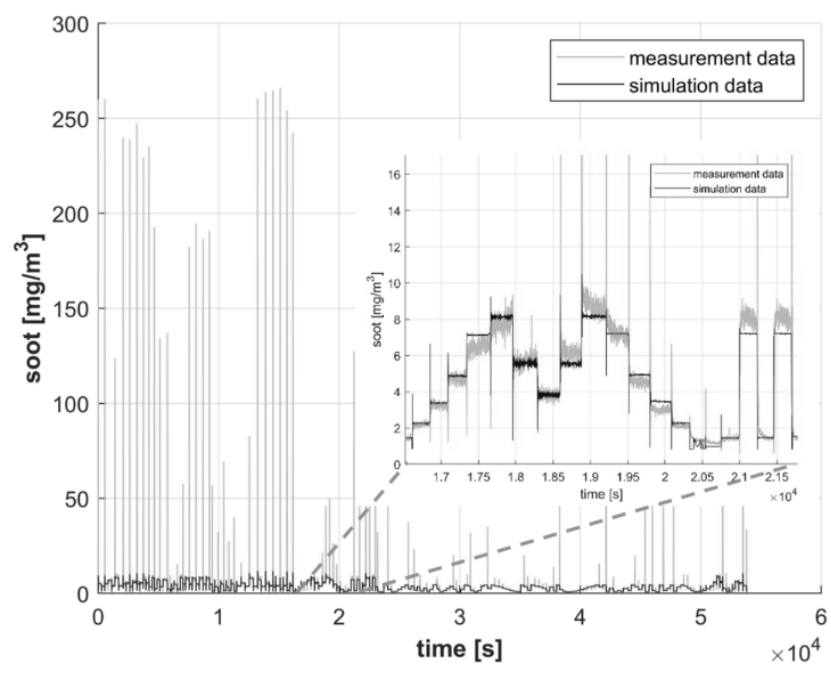

Fig. 7. Trying to simulate measured load changes by means of a static ANN

\section{ANN with external dynamics - a lookout}

In a first step, the external dynamics approach was chosen to simulate soot formation during transient operation. External dynamics means that the dynamic is generated by extension of the input space [7]. Each of the input parameters (herein $\mathrm{m}_{B}$ and $\mathrm{n}_{\mathrm{act}}$ ) needs a certain time history which is also entering the ANN. The following example takes into account each input parameter's values up to 100 seconds in the past, but only every second value is taken as additional input. Consequently, the number of inputs rises to one hundred considering $\mathrm{m}_{\mathrm{B}}$ and $\mathrm{n}_{\mathrm{act}}$.

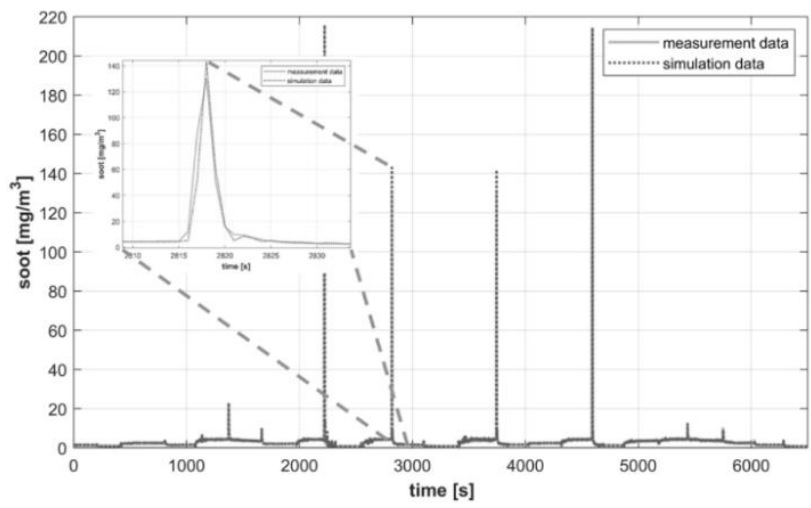

Fig. 8. Validation data set (light grey solid line) and simulation of this same data with trained ANN (dark grey dotted line)

The increased input number also requires an increased number of hidden neurons and training data. The optimum for the three setting parameters - the past values and their intervals as well as the number of hidden neurons - is still to be investigated for the present problem. So far, the following example shows an ANN with external dynamics taking the above described number of input values and 20 hidden neurons. The training data set comprises $75 \%$ of the available data in generator mode. The remaining $25 \%$ of measurement data was used for validation (Fig. 8). For a first attempt the ANN with external dynamics is able to identify the instationarities and to follow the characteristics of the soot peaks. By using different parameter settings, even better results might be expected.

\section{Summary}

In this paper, it was shown that soot produced during the transient operation of a 4-stroke marine diesel engine can be reproduced very well with the help of a stationary ANN that contains 6 up to 15 neurons in the hidden layer. Investigations on the use of an ANN with external dynamics for the simulation of transient engine operation are currently in progress and appear to be promising as suggested in the work of [6] for the application for high-speed diesel engines. Besides the different dynamic behaviour of a passenger car and a ship diesel engine, the biggest difference between the two engine types are the availability and the operational costs of testbed engines.

The next step will be the integration of the ANN into a suitable ship model and its use within the SAMMON software for verification of the entire method from testbed trials until the application in the prediction software. The perspective is to take measurement data from a real ship in order to simulate both, the ship's motion as well as its fuel consumption and emissions within the assistance software SAMMON.

\section{References}

[1] Ayoubi M.: Nonlinear system identification based on neural networks with locally distributed dynamics and application to technical processes. VDI edition, Düsseldorf 1996.

[2] Bockhorn H.: Soot formation in combustion. Springer edition, Berlin/Heidelberg 1994.

[3] Dahms F., Reska M., Nocke J., Hassel E., Reißig M., Schaub M.: Characterizing of transient engine operating with investigation on particle size distribution on a four-stroke medium-speed engine. CIMAC 2019.

[4] http://www.imo.org/en/KnowledgeCentre/IndexofIMOResolutions/MarineEnvironment-Protection-Committee-(MEPC)/Documents/MEPC.176(58).pdf (available: 24.07.2019).

[5] https://issims-gmbh.com/yoomla/products/sammon (available: 24.07.2019).

[6] Isermann R.: Engine Modeling and Control. Springer edition, Heidelberg 2014.

[7] Nelles O.: Nonlinear System Identification. Springer, Heidelberg 2001.

[8] Rohs H.: Simulation des transienten Betriebsverhalten von aufgeladenen Dieselmotoren. PhD Thesis, TH Aachen, 2006.

[9] Schaub M., Finger G., Dahms F., Hassel E., Jeinsch T., Kirchhoff M.: Databased prediction of particle emissions during manoeuvring of ships. IIPhdW 2019

[10] Schaub M., Finger G., Riebe T., Dahms F., Hassel E., Baldauf M.: Data-based modelling of ship emissions and fuel oil consumption for transient engine operation. OCEANS 2019 .

[11] Wenzel S.P.: Modellierung der Ruß- und $\mathrm{NO}_{\mathrm{X}}$-Emissionen des Dieselmotors. $\mathrm{PhD}$ thesis, Otto-von-Guericke-Universität Magdeburg, 2006.
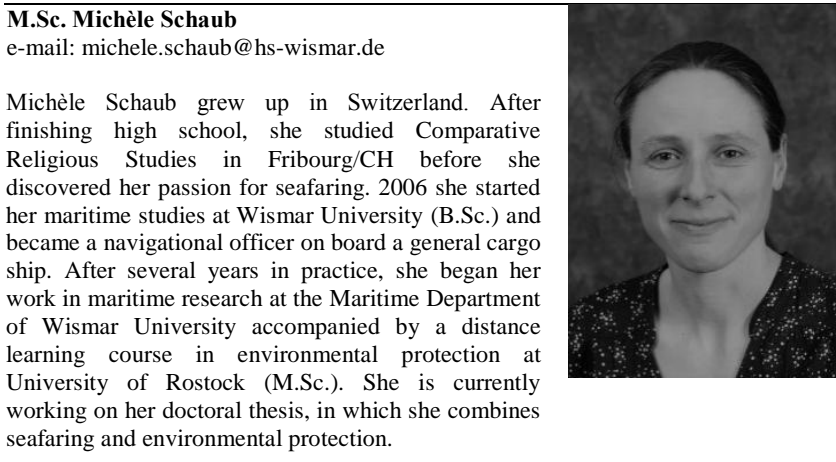
working on her doctoral thesis, in which she combines ORCID ID: 0000-0002-3566-7572

otrzymano/received: 02.08 .2019 